\title{
Most cited articles: ethanol-induced hepatotoxicity, anticarcinogenic effects of polyphenolic compounds in tea, dose-response modeling, novel roles of epoxide hydrolases and arsenic-induced suicidal erythrocyte death
}

\author{
H. M. Bolt • J. G. Hengstler
}

Published online: 18 November 2011

(C) Springer-Verlag 2011

Every year, the editors of the Archives of Toxicology review the most cited articles from the previous 2 years (Table 1). This year, topping the most cited list (51 citations) is a comprehensive review by Arthur I. Cederbaum on the mechanisms of ethanol-induced liver injury, describing the contributions of oxidative stress and CYP2E1. The second most cited article also focuses on oxidative stress, but from a different perspective. Chung $\mathrm{S}$. Yang describes how polyphenolic compounds in tea act as anticarcinogens. Besides their antioxidant properties, polyphenolic compounds prevent DNA damage and modulate carcinogen metabolism. Metabolic detoxification of carcinogens is also catalyzed by epoxide hydrolases. Martina Decker and colleagues contributed a comprehensive review, in which they describe that epoxide hydrolases play a role not only in detoxification but also in signaling processes by metabolizing lipids, thereby influencing blood pressure and inflammation. Edward J. Calabrese critically discusses why the hormesis model became marginalized in dose-response modeling. Finally, the most frequently cited original article was published by Hasan Mahmud and colleagues. They show that arsenic induces suicidal death of erythrocytes by increasing cytosolic $\mathrm{Ca}^{2+}$ concentrations, which may explain why environmental arsenic exposure causes anemia. Table 1 provides highlights of the most cited articles of 2009 and 2010.

H. M. Bolt $(\bowtie) \cdot$ J. G. Hengstler

Leibniz Institut für Arbeitsforschung an der TU Dortmund, Leibniz Research Centre for Working Environment and Human Factors (IfADo), Ardeystrasse 67, 44139 Dortmund, Germany e-mail: bolt@ifado.de

\section{References}

Angeli JP, Ribeiro LR, Bellini MF, Mantovani MS (2009) Betaglucan extracted from the medicinal mushroom Agaricus blazei prevents the genotoxic effects of benzo[a]pyrene in the human hepatoma cell line HepG2. Arch Toxicol 83(1):81-86

Calabrese EJ (2009a) The road to linearity: why linearity at low doses became the basis for carcinogen risk assessment. Arch Toxicol 83(3):203-225

Calabrese EJ (2009b) Getting the dose-response wrong: why hormesis became marginalized and the threshold model accepted. Arch Toxicol 83(3):227-247

Cederbaum AI, Lu Y, Wu D (2009) Role of oxidative stress in alcohol-induced liver injury. Arch Toxicol 83(6):519-548

Cervinková Z, Kriváková $\mathrm{P}$, Lábajová A, Rousar T, Lotková H, Kucera O, Endlicher R, Cervinka M, Drahota Z (2009) Mechanisms participating in oxidative damage of isolated rat hepatocytes. Arch Toxicol 83(4):363-372

Chen YM, Guo LH (2009) Fluorescence study on site-specific binding of perfluoroalkyl acids to human serum albumin. Arch Toxicol 83(3):255-261

Decker M, Arand M, Cronin A (2009) Mammalian epoxide hydrolases in xenobiotic metabolism and signalling. Arch Toxicol 83(4):297-318

Dewa Y, Nishimura J, Muguruma M, Jin M, Kawai M, Saegusa Y, Okamura T, Umemura T, Mitsumori K (2009) Involvement of oxidative stress in hepatocellular tumor-promoting activity of oxfendazole in rats. Arch Toxicol 83(5):503-511

Dong GH, Zhang YH, Zheng L, Liu W, Jin YH, He QC (2009) Chronic effects of perfluorooctanesulfonate exposure on immunotoxicity in adult male C57BL/6 mice. Arch Toxicol 83(9): 805-815

Drobná Z, Walton FS, Paul DS, Xing W, Thomas DJ, Stýblo M (2009) Metabolism of arsenic in human liver: the role of membrane transporters. Arch Toxicol 84(1):3-16

Furuyama A, Kanno S, Kobayashi T, Hirano S (2009) Extrapulmonary translocation of intratracheally instilled fine and ultrafine particles via direct and alveolar macrophage-associated routes. Arch Toxicol 83(5):429-437

Grotto D, Barcelos GR, Valentini J, Antunes LM, Angeli JP, Garcia SC, Barbosa F Jr (2009a) Low levels of methylmercury induce DNA damage in rats: protective effects of selenium. Arch Toxicol 83(3):249-254 
Table 1 Most cited articles in the Archives of Toxicology in 2009 and 2010

\begin{tabular}{lll}
\hline No. & Author & Take home message \\
\hline 1 & $\begin{array}{c}\text { Cederbaum et al. } \\
\text { (2009) }\end{array}$ & $\begin{array}{l}\text { This is a comprehensive review explaining how ethanol-induced oxidative stress produces liver injury. Special } \\
\text { emphasis is placed on ethanol-induced CYP2E1 induction }\end{array}$ \\
$2 \quad$ Yang et al. (2009a, b) & $\begin{array}{l}\text { Polyphenolic compounds in tea are suggested to have anticarcinogenic properties because they modulate } \\
\text { carcinogen metabolism, prevent DNA damage and decrease oxidative stress. This review critically discusses } \\
\text { possible anticarcinogenic effects of tea polyphenols and summarizes published evidence from animal models of } \\
\text { carcinogenesis as well as epidemiological studies }\end{array}$
\end{tabular}

3 Calabrese (2009a, b) The scientific community has shown preference to the threshold dose-response rather than the hormesis model. This is critically discussed, because the hormesis model may be superior in predicting responses in the low dose range

$4 \quad$ Decker et al. (2009)

Besides their role in detoxification, epoxide hydrolases are involved in signaling processes by metabolizing signaling lipids. This process seems to be relevant for the control of blood pressure, inflammation, proliferation and nociception

$5 \quad$ Mahmud et al. (2009) Arsenic triggers suicidal erythrocyte death by increasing cytosolic $\mathrm{Ca}^{2+}$ concentrations. This may explain why environmental exposure to arsenic may lead to anemia

6 Calabrese (2009a, b) Linearity at low doses has become the basis for carcinogen risk assessment. The author criticizes this concept by re-visiting its foundations

$7 \quad$ Furuyama et al.

8 Zheng et al. (2009)

$9 \quad \mathrm{Hu}$ and $\mathrm{Hu}(2009)$

10 Nakagawa et al. (2009)

Ultrafine particles can be transported into the blood across the alveolar wall by endocytic pathways. In contrast, macrophages translocate not only ultrafine but also fine particles from the lung to other organs

Oral exposure of mice to the environmental contaminant perfluoro-octanesulfonate causes immunotoxic changes

Combined exposure of HepG2 cells to the environmental contaminants perfluorooctanoate and perfluorooctane sulfonate causes summation effects, but not synergistic or antagonistic effects

The designer drugs MDMA and derivatives are illegally used as recreational drugs. Unfortunately, some are hepatotoxic in humans. The present study shows that some amphetamine-derived drugs cause mitotoxicity and DNA damage in primary hepatocytes

11 Kumar and Gill (2009)

12 Chen et al. (2009)

13 Grotto et al. (2009a, b)

14 Dewa et al. (2009)

Aluminum is the most widely distributed metal in the environment. This review describes mechanisms of aluminum-induced neurotoxicity, including mitochondrial stress and the accumulation of oxidized proteins

Perfluoroalkyl acids show a site-specific binding to human serum albumin

Selenium antagonizes the genotoxic and oxidative properties of low doses of methylmercury in rats

The benzimidazole anthelmintic oxfendazole causes oxidative stress in livers of rats, which may contribute to tumor promotion

15 Grotto et al. (2009a, b)

Exposure of rats to low doses of methylmercury causes hypertension. Possible mechanisms are nitric oxide depletion and oxidative damage

16 Kell (2010)

The author established a general concept of how poorly liganded iron is involved in the pathogenesis of several diseases, including Parkinson's, Huntington's and Alzheimer's disease. Possible interventions with iron chelators and antioxidants are discussed

17 Sebai et al. (2009)

Resveratrol protects from LPS-induced inflammation in rats

18 Valdiglesias et al. (2010)

19 Pestka (2010)

Selenium may have anticarcinogenic effects at low concentrations, but may be genotoxic and carcinogenic at higher concentrations. This comprehensive review summarizes the results of in vitro studies on mutagenicity, genotoxicity, cytotoxcity and DNA repair with selenium compounds from the last decades

The trichothecene mycotoxin deoxynivalenol (DON), also known as vomitoxin, is formed by the fungus Fusarium on wheat, barley and corn. This review gives an overview of human exposure, toxicity and mechanisms of action, including ribotoxic stress, compromised signal transduction, differentiation and proliferation

20 Helal and Helal (2009)

21 Schumann et al. (2009)

22 Wang et al. (2009a, b)

Exogenously administered metallothionein protects against carmustine-induced pulmonary fibrosis in rats

A novel thermoluminescence-based technique for the quantification of oxidative stress in mammalian cells or tissues has been established. In contrast to biochemical analysis, this assay can be performed without extraction or specific preparation procedures by using directly collected material

Arsenic induces apoptosis in hepatocytes by the mitochondrial pathway

23 Drobná et al. (2009)

The relationship between potential arsenic transporters and cellular retention of inorganic arsenic and its methylated metabolites was analyzed. High MRP2 expression correlated with the production of dimethylarsenic metabolites

24 Zhu et al. (2009)

Exposure to the radioactive heavy metal depleted uranium can occur via inhalation of aerosols, ingestion and wounds. Implantation of depleted uranium into rats caused renal dysfunction 
Table 1 continued

\begin{tabular}{lll}
\hline No. & Author & Take home message \\
\hline 25 & Lu et al. (2009) & Extracts of Antrodia camphorate cause apoptosis of HL 60 cells \\
26 & Dong et al. (2009) & Exposure of mice to perfluorooctanesulfonate at levels 50-fold higher than highly exposed humans affect immune
\end{tabular}

26 Dong et al. (2009) functions

27 Xie et al. (2010)

The long-term quantitative biodistribution of silica nanoparticles was studied in mice. Silica nanoparticles accumulate in lung, liver and spleen because of endocytosis by macrophages

28 Yang et al. (2009a, b)

No significant differences in bisphenol A blood levels were obtained between breast cancer cases and controls

29 Cervinková et al.

Sensitive indicators of peroxidative damage induced by tert-butyl hydroperoxide in primary rat hepatocytes (2009)

30 Stangherlin et al. (2009)

31 Wang et al.

(2009a, b)

32 Yan et al. (2009) include a decrease in cytosolic glutathione and discharge of the mitochondrial membrane potential

Exposure of young rats to diphenyl ditelluride via maternal milk causes oxidative stress in the cerebral cortex and hippocampus

Lead acetate causes oxidative stress and apoptosis in primary cultures of rat proximal tubular cell

Excessive intake of sodium fluoride may compromise the balance between bone formation and resorption leading to skeletal disease. This study showed that already relatively low fluoride concentrations may cause apoptosis of osteoblasts

33 Rand et al. (2010)

Damp building materials may host the anamorphic Trichocomaceae that form (1-3)-beta-d-glucan. This study demonstrates that (1-3)-beta-d-glucan causes an inflammation-associated gene expression pattern in mouse lungs

34 Magdalan et al. (2009)

This study describes the time course of alpha-amanitin toxicity in primary cultivated hepatocytes. Functional cells impairments such as inhibition of protein and urea synthesis are followed by changes in ultrastructure (marginalization and condensation of nuclear chromatin) and necrosis as well as apoptosis

35 Morfeld (2009)

36 Stapleton and Chan (2009)

37 Huang et al. (2009)

In this letter, statistical analysis of an epidemiological study on the possible link between traffic-related atmospheric pollutants and birth weight is critically discussed

The commonly used organophosphorus insecticide, chlorpyrifos alters expression of genes involved in neurological functions and development in the forebrain of rats at subtoxic doses

A simple, fast and economic method for the simultaneous detection of aflatoxin B1 and ochratoxin A was established

38 Xi et al. (2009)

Exposure of pregnant rat dams and offspring pups to inorganic arsenite in drinking water at levels up to $100 \mathrm{mg} / \mathrm{l}$ affects learning and memory functions

39 Zeng and Xie (2009)

Ethanol-induced steatosis represents a frequent health problem. Here, the role of the nuclear transcription factors PPAR alpha, SREBP-1 and the role of CYP2E1 are discussed

$40 \quad$ Read et al. (2010)

Phosphorylated butylcholinesterase and phosphorylated albumin are compared as biomarkers of organophosphorus exposure in guinea pigs

41 Kawai et al. (2010)

Piperonyl butoxide contributes to liver tumor promotion in mice by generation of reactive oxygen species

42 Prigol et al. (2010)

43 Angeli et al. (2009)

The organoselenium compound diphenyl diselenide caused seizure episodes in rat pups. The pups with the highest levels of diphenyl diselenide in liver and brain showed the shortest latency periods

44 Ito et al. (2009) The medicinal mushroom Agaricus blazei is discussed as an antimutagen
antagonizes the genotoxic effect of benzo[a]pyrene in HepG2 cells

Fluoride-induced degranulation of rat exocrine pancreas cells represents a turning point from autophagy to apoptosis

45 Sanchez et al. (2009)

46 Kesarwani et al. (2009)

47 Sidiropoulou et al. (2009)

Colombostatin, a novel disintegrin, was isolated from the venom of the South American snake, Bothrops colombiensis. It was shown to inhibit platelet aggregation and thus represents a drug candidate for the treatment of thrombotic diseases

An association between a GSTM3 intron 6 variant and prostate cancer risk was observed in a North Indian casecontrol study

Diazinon oxon is a major in vivo metabolite of the phosphorothionate insecticide diazinon, which affects the differentiation of neuroblastoma cells in vitro

48 Rizzi et al. (2009)

Matrix metalloproteinase-2 plays a role in lead-induced hypertension

49 Heng et al. (2009)

This minireview discusses possibilities and limitations of using induced pluripotency stem cells in toxicity testing

50 Shimizu et al. (2009)

A glutathione-depleted mouse model was introduced to identify amodiaquine as an idiosyncratic hepatotoxic compound 
Grotto D, de Castro MM, Barcelos GR, Garcia SC, Barbosa F Jr (2009b) Low level and sub-chronic exposure to methylmercury induces hypertension in rats: nitric oxide depletion and oxidative damage as possible mechanisms. Arch Toxicol 83(7):653-662

Helal GK, Helal OK (2009) Metallothionein attenuates carmustineinduced oxidative stress and protects against pulmonary fibrosis in rats. Arch Toxicol 83(1):87-94

Heng BC, Richards M, Shu Y, Gribbon P (2009) Induced pluripotent stem cells: a new tool for toxicology screening? Arch Toxicol 83(7):641-644

Hu XZ, Hu DC (2009) Effects of perfluorooctanoate and perfluorooctane sulfonate exposure on hepatoma Hep G2 cells. 34. Arch Toxicol 83(9):851-861

Huang B, Xiao H, Zhang J, Zhang L, Yang H, Zhang Y, Jin J (2009) Dual-label time-resolved fluoroimmunoassay for simultaneous detection of aflatoxin B1 and ochratoxin A. Arch Toxicol 83(6):619-624

Ito M, Nakagawa H, Okada T, Miyazaki S, Matsuo S (2009) ER-stress caused by accumulated intracistanal granules activates autophagy through a different signal pathway from unfolded protein response in exocrine pancreas cells of rats exposed to fluoride. Arch Toxicol 83(2):151-159

Kawai M, Saegusa Y, Dewa Y, Nishimura J, Kemmochi S, Harada T, Ishii Y, Umemura T, Shibutani M, Mitsumori K (2010) Elevation of cell proliferation via generation of reactive oxygen species by piperonyl butoxide contributes to its liver tumorpromoting effects in mice. Arch Toxicol 84(2):155-164

Kell DB (2010) Towards a unifying, systems biology understanding of large-scale cellular death and destruction caused by poorly liganded iron: Parkinson's, Huntington's, Alzheimer's, prions, bactericides, chemical toxicology and others as examples. Arch Toxicol 84(11):825-889 (Comment in Arch Toxicol 2010 84(11):823-824)

Kesarwani P, Singh R, Mittal RD (2009) Association of GSTM3 intron 6 variant with cigarette smoking, tobacco chewing and alcohol as modifier factors for prostate cancer risk. Arch Toxicol 83(4):351-356

Kumar V, Gill KD (2009) Aluminium neurotoxicity: neurobehavioural and oxidative aspects. Arch Toxicol 83(11):965-978

Lu MC, Du YC, Chuu JJ, Hwang SL, Hsieh PC, Hung CS, Chang FR, Wu YC (2009) Active extracts of wild fruiting bodies of Antrodia camphorata (EEAC) induce leukemia HL 60 cells apoptosis partially through histone hypoacetylation and synergistically promote anticancer effect of trichostatin A. Arch Toxicol 83(2):121-129

Magdalan J, Ostrowska A, Podhorska-Okołów M, Piotrowska A, Izykowska I, Nowak M, Dolińska-Krajewska B, Zabel M, Szelag A, Dziegiel P (2009) Early morphological and functional alterations in canine hepatocytes due to alpha-amanitin, a major toxin of Amanita phalloides. Arch Toxicol 83(1):55-60

Mahmud H, Föller M, Lang F (2009) Arsenic-induced suicidal erythrocyte death. Arch Toxicol 83(2):107-113

Morfeld P (2009) A plea for rigorous and honest science: false positive findings and biased presentations in epidemiological studies. Arch Toxicol 83(2):105-106 (Comment in Arch Toxicol 2009 83(6):517-158; author reply 515; Arch Toxicol 2009 83(4):293-295)

Nakagawa Y, Suzuki T, Tayama S, Ishii H, Ogata A (2009) Cytotoxic effects of 3, 4-methylenedioxy-N-alkylamphetamines, MDMA and its analogues, on isolated rat hepatocytes. Arch Toxicol 83(1):69-80

Pestka JJ (2010) Deoxynivalenol: mechanisms of action, human exposure, and toxicological relevance. Arch Toxicol 84(9): 663-679

Prigol M, Pinton S, Schumacher R, Nogueira CW, Zeni G (2010) Convulsant action of diphenyl diselenide in rat pups: measurement and correlation with plasma, liver and brain levels of compound. Arch Toxicol 84(5):373-378

Rand TG, Sun M, Gilyan A, Downey J, Miller JD (2010) Dectin-1 and inflammation-associated gene transcription and expression in mouse lungs by a toxic $(1,3)$-beta-D glucan. Arch Toxicol 84(3):205-220

Read RW, Riches JR, Stevens JA, Stubbs SJ, Black RM (2010) Biomarkers of organophosphorus nerve agent exposure: comparison of phosphylated butyrylcholinesterase and phosphylated albumin after oxime therapy. Arch Toxicol 84(1):25-36

Rizzi E, Castro MM, Fernandes K, Barbosa F Jr, Arisi GM, GarciaCairasco N, Bendhack LM, Tanus-Santos JE, Gerlach RF (2009) Evidence of early involvement of matrix metalloproteinase-2 in lead-induced hypertension. Arch Toxicol 83(5):439-449

Sánchez EE, Rodríguez-Acosta A, Palomar R, Lucena SE, Bashir S, Soto JG, Pérez JC (2009) Colombistatin: a disintegrin isolated from the venom of the South American snake (Bothrops colombiensis) that effectively inhibits platelet aggregation and SK-Mel-28 cell adhesion. Arch Toxicol 83(3):271-279

Schumann A, Bauer A, Hermes M, Gilbert M, Hengstler JG, Wilhelm C (2009) A rapid and easy to handle thermoluminescence based technique for evaluation of carbon tetrachloride-induced oxidative stress on rat hepatocytes. Arch Toxicol 83(7):709-720

Sebai H, Ben-Attia M, Sani M, Aouani E, Ghanem-Boughanmi N (2009) Protective effect of resveratrol in endotoxemia-induced acute phase response in rats. Arch Toxicol 83(4):335-340

Shimizu S, Atsumi R, Itokawa K, Iwasaki M, Aoki T, Ono C, Izumi T, Sudo K, Okazaki O (2009) Metabolism-dependent hepatotoxicity of amodiaquine in glutathione-depleted mice. Arch Toxicol 83(7):701-707

Sidiropoulou E, Sachana M, Flaskos J, Harris W, Hargreaves AJ, Woldehiwet Z (2009) Diazinon oxon affects the differentiation of mouse $\mathrm{N}_{2}$ a neuroblastoma cells. Arch Toxicol 83(4):373-380

Stangherlin EC, Ardais AP, Rocha JB, Nogueira CW (2009) Exposure to diphenyl ditelluride, via maternal milk, causes oxidative stress in cerebral cortex, hippocampus and striatum of young rats. Arch Toxicol 83(5):485-491

Stapleton AR, Chan VT (2009) Subtoxic chlorpyrifos treatment resulted in differential expression of genes implicated in neurological functions and development. Arch Toxicol 83(4): 319-333

Valdiglesias V, Pásaro E, Méndez J, Laffon B (2010) In vitro evaluation of selenium genotoxic, cytotoxic, and protective effects: a review. 64. Arch Toxicol 84(5):337-351

Wang L, Liu J, Pi C, Zeng X, Zhou M, Jiang X, Chen S, Ren Z, Xu A (2009a) Identification of a novel M-superfamily conotoxin with the ability to enhance tetrodotoxin sensitive sodium currents. Arch Toxicol 83(10):925-932

Wang Y, Xu Y, Wang H, Xue P, Li X, Li B, Zheng Q, Sun G (2009b) Arsenic induces mitochondria-dependent apoptosis by reactive oxygen species generation rather than glutathione depletion in Chang human hepatocytes. Arch Toxicol 83(10):899-908

Xi S, Sun W, Wang F, Jin Y, Sun G (2009) Transplacental and early life exposure to inorganic arsenic affected development and behavior in offspring rats. Arch Toxicol 83(6):549-556

Xie G, Sun J, Zhong G, Shi L, Zhang D (2010) Biodistribution and toxicity of intravenously administered silica nanoparticles in mice. Arch Toxicol 84(3):183-190

Yan X, Feng C, Chen Q, Li W, Wang H, Lv L, Smith GW, Wang J (2009) Effects of sodium fluoride treatment in vitro on cell proliferation, apoptosis and caspase- 3 and caspase-9 mRNA expression by neonatal rat osteoblasts. Arch Toxicol 83(5): $451-458$

Yang CS, Lambert JD, Sang S (2009a) Antioxidative and anticarcinogenic activities of tea polyphenols. Arch Toxicol 83(1): $11-21$ 
Yang M, Ryu JH, Jeon R, Kang D, Yoo KY (2009b) Effects of bisphenol A on breast cancer and its risk factors. Arch Toxicol 83(3):281-285

Zeng T, Xie KQ (2009) Ethanol and liver: recent advances in the mechanisms of ethanol-induced hepatosteatosis. Arch Toxicol 83(12):1075-1081
Zheng L, Dong GH, Jin YH, He QC (2009) Immunotoxic changes associated with a 7-day oral exposure to perfluorooctanesulfonate (PFOS) in adult male C57BL/6 mice. 81. Arch Toxicol 83(7):679-689

Zhu G, Xiang X, Chen X, Wang L, Hu H, Weng S (2009) Renal dysfunction induced by long-term exposure to depleted uranium in rats. Arch Toxicol 83(1):37-46 